\title{
IMMUNOBIOLOGICAL ACTIONS OF ANTISERUM TO OVINE PROLACTIN IN MICE
}

\author{
TARALA V. PURANDARE, B. DATTATREYMURTY, \\ SAFIA R. MUNSHI AND SHANTA S. RAO \\ Division of Fundamental Research, Institute for Research in Reproduction \\ (ICMR), Jehangir Merwanji Street, Parel, Bombay 400 012, India
}

(Received 23rd September 1974)

\begin{abstract}
Summary. Neutralization of pituitary prolactin by the administration of antiserum to prolactin in the mouse selectively blocked the pro-oestrous stage of the oestrous cycle and inhibited ovulation in normal cyclic mice. In pseudopregnant mice, the antiserum shortened the duration of pseudopregnancy. Failure of the antiserum to affect uterine cell division, blastocyst implantation and pregnancy suggests that the secretion of progesterone by the luteal tissue appears to be more influenced by $\mathrm{LH}$ than by prolactin.
\end{abstract}

\section{INTRODUCTION}

In the female, it is well documented that FSH brings about the maturation of the ovarian follicles and the subsequent growth of the ovaries. On the other hand, LH has been associated with the secretion of oestrogen, with the consequent stimulation of ovulation and the conversion of the follicle into a CL (Donovan \& Lockhart, 1972). Prolactin has been shown to exert a luteotrophic action on newly formed CL and a luteolytic effect on the older CL (Malven \& Sawyer, 1966; Grandison \& Meites, 1972). Although these three gonadotrophins are generally implicated in the control of ovarian function, the role of the latter seems to vary from species to species.

Studies in our laboratory have demonstrated that antiserum to ovine LH inhibited the endogenous LH activity in immature rats. Continuous injections of antiserum in the mouse prevented the occurrence of normal oestrous cycles, decreased the weights of the reproductive organs, inhibited blastocyst implantation and caused resorption of implanted fetuses (Munshi \& Rao, 1967). A single injection of antiserum to $\mathrm{LH}$ given during the preimplantation stage of pregnancy impeded the production of progesterone, thereby inhibiting pregnancy as well as the decidual cell reaction in pseudopregnant mice (Munshi et al., 1972). Treatment with LH antiserum did not affect implantation of the blastocysts (Munshi \& Nilsson, 1973) or uterine cell division (Munshi et al., 1973). Antiserum to ovine FSH, however, did not have any deleterious effect on any of the reproductive functions in the mouse (Munshi \& Rao, 1968).

Prolactin is known to be secreted by the pituitary gland during pro-oestrus. Several workers have reported that concentrations of serum prolactin are high 
during pro-oestrus and oestrus, and reach peak levels during the afternoon of pro-oestrus (Kwa \& Verhofstad, 1967; Niswender et al., 1969; Gay et al., 1970; Wuttke \& Meites, 1970; Neill et al., 1971). Macdonald et al. (1971) demonstrated that prolactin prolongs the life-span of the CL. Astwood \& Greep (1938) and Cerrutti \& Lyons (1960) have reported that the placenta secretes prolactin. It was of interest therefore to investigate whether antiserum to prolactin would have deleterious effects on any of the reproductive functions in the mouse.

\section{MATERIALS AND METHODS}

\section{Hormones}

The ovine prolactin (NIH-P-S10) and ovine growth hormone (NIH-GH-S10) used in this study were prepared and characterized for the Endocrinology Study Section by Dr L. E. Reichert, Jr. The GH activity in NIH-P-S10 was reported to be less than 0.010 i.u./mg. The prolactin activity in NIH-GH-S10 was reported to be less than 3 i.u./mg.

\section{Animals}

The inbred Swiss-strain female mice and the rabbits used in the study were from the animal colony of the Institute. Four to five mice were caged together and maintained in an animal room at a constant temperature of $70^{\circ} \mathrm{F}$ and a lighting schedule of $12 \mathrm{hr}$ light/12 hr dark. Rabbits weighing $2.5 \mathrm{~kg}$ were used for the preparation of antiserum.

\section{Preparation of the antiserum}

Antiserum to ovine prolactin was prepared in rabbits according to the method of Munshi \& Rao (1965), except that the booster dose of prolactin was injected intraperitoneally. The double diffusion technique of Ouchterlony (1949) was used to characterize the antiserum. The precipitin test (Kabat \& Mayer, 1961) and the haemagglutination test (Rao \& Sadri, 1959) using cells treated with formalin (Raghavan et al., 1973) was used for the quantification of the antibodies in the antiserum.

The analytical polyacrylamide disc gel electrophoretic procedure of Davis (1964) was employed with slight modifications. A sample of about $200 \mu \mathrm{g}$ of protein in 10 to $30 \mu \mathrm{l}$ of $0.05 \mathrm{M}-\mathrm{NaHCO}_{3}$ buffer $(\mathrm{pH} \mathrm{9.2)}$ was placed over the spacer gel. The volume was made up to $0.1 \mathrm{ml}$ with $0.5 \mathrm{M}$ - sucrose and mixed thoroughly. The upper reservoir buffer was placed slowly on it to form a separate layer. Electrophoresis was carried out using tris-glycine buffer, $\mathrm{pH} 8.9$. Unstained, longitudinally sliced polyacrylamide gels were embedded in $1.5 \%$ agar solution in $0.15 \mathrm{~m}$-sodium chloride on a glass Petri dish, immediately following the electrophoresis. After solidification of the agar, a 2-mm slit was cut on both the sides of the gels and at a distance of $4 \mathrm{~mm}$. The slits were filled to the brim with unabsorbed or absorbed antiserum to ovine prolactin. The plates were kept in aqueous saturated chambers at $4^{\circ} \mathrm{C}$ for 2 to 3 days.

Pooled antiserum (ASOP) absorbed free of GH contaminant was used for the biological studies. 
The growth hormone $(\mathrm{GH})$ contaminant in the antiserum was removed by absorption with water-insoluble immunoabsorbents of GH prepared by the method of Avrameas \& Ternynck (1969) involving a 2.5\% glutaraldehyde solution as a cross-linking agent. The immunoabsorbent was stored at $4^{\circ} \mathrm{C}$, centrifuged before use and the supernatant was discarded. The polymerized antigen so obtained was resuspended in $50 \mathrm{ml}$ of the antiserum to ovine prolactin, stirred and kept for $60 \mathrm{~min}$ at room temperature. The supernatant was centrifuged at $3000 \mathrm{rev} / \mathrm{min}$ for $15 \mathrm{~min}$ and the precipitate was discarded. The supernatant antiserum was used in the studies reported here.

\section{Effect of pooled antiserum on ovulation}

Oestrous cycles were followed by examining daily vaginal smears for 2 weeks before beginning the experiments. Mice with regular cycles were selected and five groups, each consisting of seven to eight mice, were used for the study. The first group of mice served as controls. The second group was injected subcutaneously with $0.1 \mathrm{ml}$ normal rabbit serum (NRS)/day for 15 days. The third group of mice received a single subcutaneous injection of $0.2 \mathrm{ml}$ ASOP on the day of dioestrus. In the fourth group, $0.2 \mathrm{ml}$ ASOP was injected on the day of metoestrus and the day of dioestrus. The fifth group of mice received $0.2 \mathrm{ml}$ ASOP daily for the duration of one complete oestrous cycle, and the last group received $0.2 \mathrm{ml}$ ASOP for 15 days. Daily vaginal smears were taken during the entire treatment period. All mice were killed either the day after the last injection or at first oestrus. At autopsy, the oviducts of all the mice were examined for the presence of ova. Control mice, maintained for the same period of time as the experimental groups, were also killed during pro-oestrus and their oviducts were examined for the presence of ova. The ovaries and uteri were dissected free of fat and weighed to the nearest $0.1 \mathrm{mg}$ on a torsion balance. The ovaries were fixed in Bouin's fixative, embedded in paraffin wax, sectioned at $5 \mu \mathrm{m}$ and stained with haematoxylin and eosin for light microscopy.

\section{Effect of pooled antiserum on CL function in pregnant mice}

Pro-oestrous females were left overnight with fertile males and examined for vaginal plugs the next morning. The day on which a vaginal plug was found was designated Day 1 of pregnancy.

To study the effect of ASOP on uterine cell division, pregnant mice were injected on Days 1 to 3 of pregnancy. The mice in one group were killed on Day 3 and those in another group on Day 4 of pregnancy, $2 \mathrm{hr}$ after a subcutaneous injection of colchicine $(0 \cdot 1 \mathrm{mg} / 0 \cdot 1 \mathrm{ml}$ saline $)$. Adequate numbers of untreated and NRS-treated controls were also maintained. At autopsy, the uteri were fixed in Bouin's solution, embedded in paraffin wax and serial transverse sections of the middle portion of each uterine horn were cut at $5 \mu \mathrm{m}$ and stained with haematoxylin and eosin. Mitotic counts were made in two fields located on each side of the uterine lumen of each horn according to the method of Finn \& Martin (1967).

To study the effect of ASOP on pregnancy, the mice in five groups consisting of five to fifteen mated females were injected on various days of pregnancy. 
Those in the first group received $0.2 \mathrm{ml}$ NRS daily throughout the gestation period. The mice in the second, third, fourth and fifth groups were subcutaneously injected with $0 \cdot 2 \mathrm{ml}$ ASOP on Days 1 to 3,6 to 8,11 to 13 and 17 to 19 of pregnancy respectively. Treated mice, except those from the second and third groups, were killed on Day 19 of gestation. Mice in the second and third groups were killed on Day 12 of gestation. The numbers of implantation sites or fetuses were carefully noted at autopsy.

\section{Effect of pooled antiserum on $C L$ function in pseudopregnant mice}

Pro-oestrous mice were mated with vasectomized males and examined the next day for a vaginal plug. The day on which a vaginal plug was observed was designated Day 1 of pseudopregnancy. Pooled antiserum was injected subcutaneously on Days 1 and 2 of pseudopregnancy while controls received NRS injections on the same days. The last day of a dioestrous vaginal smear indicated the duration of pseudopregnancy in these mice.

To study the effect of ASOP on decidual cell response, pseudopregnant mice in two groups were injected on Days 1 to 4 with $0.2 \mathrm{ml} \mathrm{NRS}$, or ASOP, respectively. Those in a third group received a single injection of ASOP only on Day 4 of pseudopregnancy. All mice were subjected to laparotomy on Day 4 of pseudopregnancy and one horn of the uterus was traumatized by scratching with a 22-gauge needle. Mice were killed on Day 8 of pseudopregnancy and the two uterine horns were removed and weighed separately.

\section{RESULTS}

\section{Characteristics of the prolactin antiserum}

The antiserum used did not cross-react with either rabbit or sheep serum or with extracts of the pituitary, ovary, adrenal, liver, kidney, spleen, testes, uterus and placenta of the mouse as judged by the results with the Ouchterlony double-diffusion agar plates. The antiserum showed cross-reactions only with prolactin and growth hormone and not with any other ovine hormone preparation (Pl. 1, Fig. 1). Antiserum to prolactin absorbed with water-insoluble immunoabsorbent of growth hormone gave only one precipitin band with

\section{EXPLANATION OF PLATE 1}

Fig. 1. Cross-reactions of the antiserum to ovine prolactin. A, unabsorbed antiserum; 1 , ovine prolactin; 2 , ovine growth hormone; 3 , ovine luteinizing hormone; 4 , normal sheep serum.

FIG. 2. Disc gel immunodiffusion analysis of ovine growth hormone and prolactin. 1, Unstained longitudinally sliced disc electrophoresis gel column of normal sheep serum; 2 and 6 , unabsorbed antiserum to ovine prolactin; 3 , unstained longitudinally sliced disc electrophoresis gel column of ovine prolactin; 4 , antiserum to ovine prolactin absorbed with ovine growth hormone; 5, unstained longitudinally sliced disc electrophoresis gel column of ovine growth hormone.

FIG. 3. Cross-reactions of the antiserum to ovine prolactin absorbed with ovine growth hormone. A, absorbed antiserum; 1, ovine growth hormone; 2, ovine prolactin.

Fig. 4. The relationship between the disc immunodiffusion patterns of ovine $\mathrm{GH}$ and ovine prolactin. A, segment of unstained gel column of ovine prolactin containing the prolactin bands; B, a segment of unstained gel column of ovine GH corresponding to the prolactin bands; $\mathrm{C}$, antiserum to ovine prolactin absorbed with ovine $\mathrm{GH}$. 
PLATE, 1

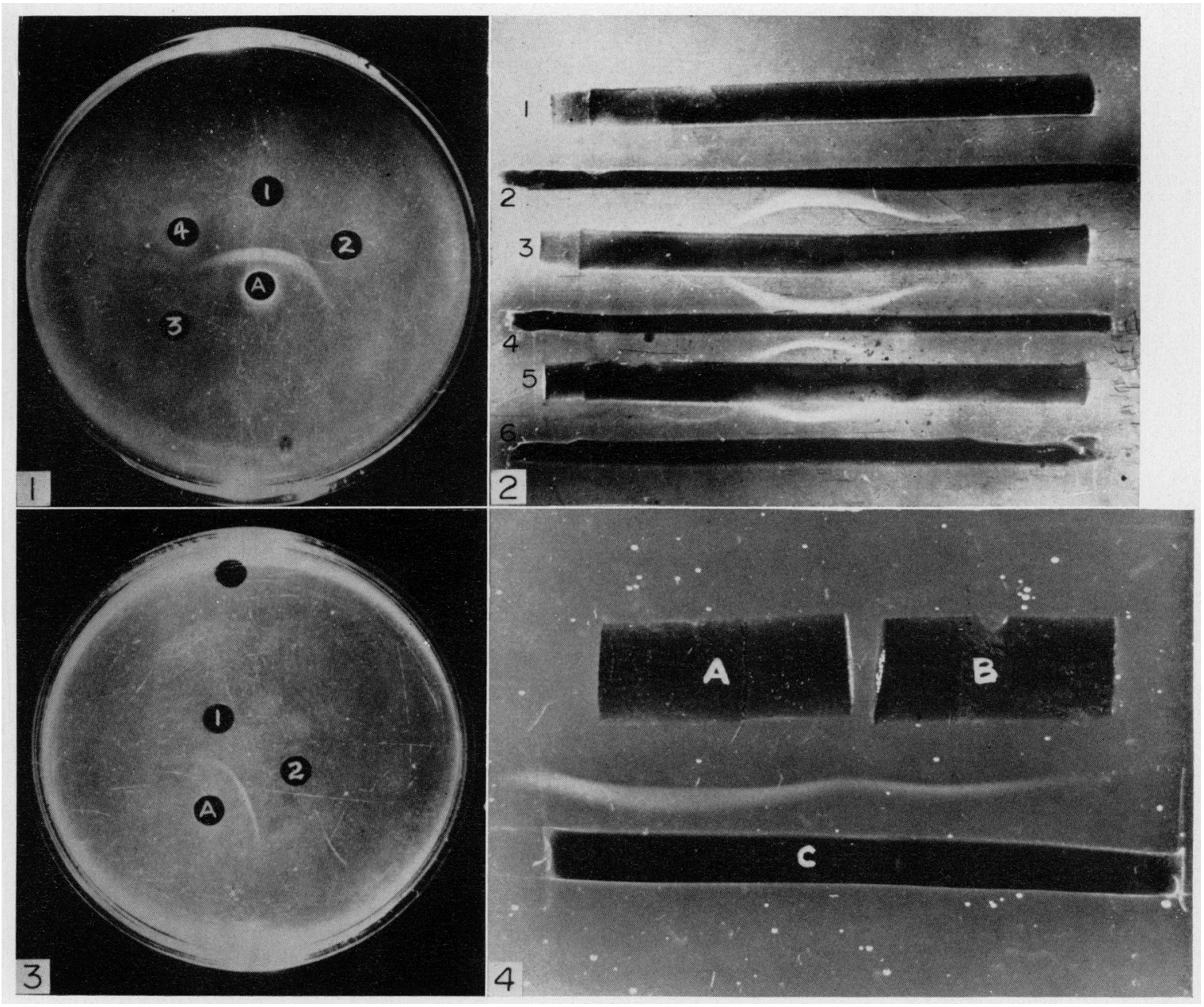

Facing (1) H1 
prolactin (Pl. 1, Fig. 3). The haemagglutination titre of the antiserum was 1:40,000 for prolactin-coated cells and as low as $1: 10$ for GH-coated cells.

In the quantitative precipitin test, solutions containing different aliquots of ovine prolactin (2 to $40 \mu \mathrm{g}$ ) in saline were added to a $0.05 \mathrm{ml}$ absorbed antiserum to ovine prolactin. After incubation and centrifugation at $3000 \mathrm{rev} / \mathrm{min}$, the supernatant was decanted carefully. The precipitate obtained was washed with saline and dissolved in $0 \cdot 1 \mathrm{~N}-\mathrm{NaOH}$. The protein content was estimated by the method of Lowry et al. (1951). The results indicated that the absorbed antiserum behaved as a homogeneous system against ovine prolactin, to give a bell-shaped precipitin curve. The maximum precipitation was obtained at a concentration of $10 \mu \mathrm{g}$ ovine prolactin (Text-fig. 1).

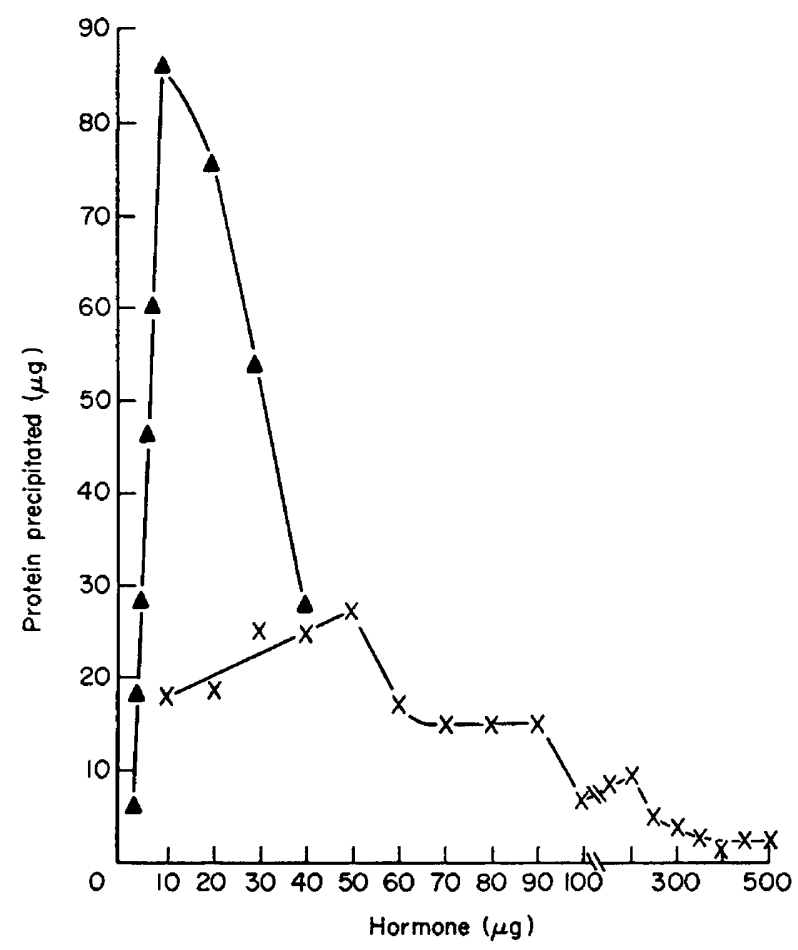

TeXT-FIG. 1. Quantitative precipitin test for ovine prolactin $(\Lambda)$ and ovine growth hormone $(x)$. The quantity of antiserum to ovine prolactin in each tube was $0.05 \mathrm{ml}$.

A similar experiment was carried out with ovine GH ( 1 to $500 \mu \mathrm{g})$ and absorbed antiserum to ovine prolactin. A low degree of cross-reaction was observed between ovine GH and the antiserum (Text-fig. 1), The highest protein complex was found at a concentration of $50 \mu \mathrm{g}$ ovine $\mathrm{GH}$, a value which was three times less than that given by ovine prolactin at the concentration of $10 \mu \mathrm{g}$.

With polyacrylamide gel electrophoresis, ovine prolactin gave three closely situated bands towards the anode, while GH gave multiple bands of which three were intensely stained and slow moving. The fast-moving bands corresponded in their electrophoretic mobility to those given by ovine prolactin. 
The disc immunodiffusion patterns of ovine $\mathrm{GH}$ and prolactin against unabsorbed and absorbed antisera to ovine prolactin are shown in Pl. 1, Fig. 2. Prolactin gave a broad precipitin arc against unabsorbed and absorbed antiserum to ovine prolactin, in the region of the three bands given by prolactin. Growth hormone gave two precipitin arcs, one in the region corresponding to the prolactin bands and the other a faint arc in the region corresponding to the intensely stained slow-moving bands situated towards the cathode. This additional precipitin arc was not seen on the gel column of GH and absorbed antiserum to ovine prolactin. Normal sheep serum did not show any crossreaction with the antiserum.

The immunological relationship between the disc immunodiffusion patterns of ovine $\mathrm{GH}$ and prolactin against absorbed antiserum was investigated. A portion of unstained gel column of ovine prolactin containing the prolactin bands (Segment A) and that of GH in the region corresponding to prolactin bands (Segment B) were cut out, embedded in agar and allowed to crossreact with absorbed antiserum to ovine prolactin. The precipitin arc given by Segment A of ovine prolactin fused with that given by Segment B of GH (Pl. 1, Fig. 4).

Table 1. Effect of pooled antiserum on ovulation and ovarian and uterine weights of cyclic female mice

\begin{tabular}{|c|c|c|c|}
\hline $\begin{array}{l}\text { Treatment group* } \\
\quad(\text { no. of mice })\end{array}$ & $\begin{array}{l}\text { No. of mice } \\
\text { with eggs in } \\
\text { oviducts }\end{array}$ & $\begin{array}{c}\text { Ovary wt } \\
(m g / 100 g \\
\text { body wt) }\end{array}$ & $\begin{array}{l}\text { Uterine } w t \\
(\mathrm{mg} / 100 \mathrm{~g} \\
\text { body } w t)\end{array}$ \\
\hline Controls (7) & $7 / 7$ & $36 \cdot 9 \pm 5 \cdot 65$ & $801 \cdot 0 \pm 118 \cdot 0$ \\
\hline NRS injected for 15 days (8) & $8 / 8$ & $35 \cdot 5 \pm 6 \cdot 50$ & $745 \cdot 3 \pm 255 \cdot 0$ \\
\hline ASOP injected on day of dioestrus (8) & $2 / 8$ & $40 \cdot 3 \pm 5 \cdot 56$ & $1187 \cdot 0 \pm 318 \cdot 0$ \\
\hline $\begin{array}{l}\text { ASOP injected on days of metoestrus and } \\
\text { dioestrus (7) }\end{array}$ & $0 / 7$ & $34-3 \pm 5 \cdot 00$ & $801 \cdot 0 \pm 356 \cdot 0$ \\
\hline ASOP injected during one oestrous cycle (7) & $0 / 7$ & $37 \cdot 3 \pm 6 \cdot 75$ & $591 \cdot 0 \pm 162 \cdot 0$ \\
\hline ASOP injected for 15 days (8) & $0 / 8$ & $36 \cdot 3 \pm 4 \cdot 00$ & $547 \cdot 0 \pm 165 \cdot 0$ \\
\hline
\end{tabular}

* $0.2 \mathrm{ml}$ pooled antiserum (ASOP) or normal rabbit serum (NRS) was injected subcutaneously at 11.00 hours.

\section{Effect of pooled antiserum on ovulation}

Control mice, untreated or injected with NRS, which were killed either on the afternoon of the day of pro-oestrus or on the morning of oestrus, had numerous ova in the oviducts. A single injection of ASOP on the day of dioestrus blocked ovulation in $6 / 8$ mice $(75 \%)$, while more than one injection of ASOP inhibited ovulation and pro-oestrus in all the animals (Table 1). Treatment with ASOP did not affect the ovarian weights of the mice, but newly formed CL were not found in any of the treated animals.

\section{Effect of pooled antiserum on uterine cell division during early pregnancy}

In mice injected with ASOP or NRS on Days 1 to 3 of pregnancy, mitotic activity was confined to the stromal cells of the uterus on Day 4. 
Effect of pooled antiserum on pregnancy

As shown in Table 2, ASOP injected during the preimplantation period inhibited implantation in only $33 \%$ of the animals, but the number of implantation sites/animal was reduced. Mice injected with ASOP during the postimplantation period (Days 6 to 8 ) had normal numbers of implantation sites. When ASOP was injected just after placental formation (Days 11 to 13), it inhibited pregnancy in $47 \%$ of the animals with a $50 \%$ reduction in the number of young per animals. When ASOP was injected just before implantation, it had no effect.

Effect of pooled antiserum on the duration of pseudopregnancy

The ASOP injected on the first 2 days of pseudopregnancy shortened $(P<0.01)$ its duration to $10.0 \pm 0.6$ (S.D.) days (six mice) compared with that of controls (12.0 \pm 1.4 days, seven mice).

Table 2. Effect of pooled antiserum on pregnancy in mice

\begin{tabular}{lcc}
\hline \multicolumn{1}{c}{ Treatment groups* } & $\begin{array}{c}\text { No. of mice } \\
\text { with implantations }\end{array}$ & $\begin{array}{c}\text { No. of } \\
\text { implantations/mouse }\end{array}$ \\
\hline Controls & $8 / 8$ & $7 \cdot 5$ \\
ASOP injected on Days 1 to 3 & $10 / 15$ & $5 \cdot 0$ \\
ASOP injected on Days 6 to 8 & $5 / 5$ & $7 \cdot 0$ \\
ASOP injected on Days 11 to 13 & $5 / 11$ & 3.8 \\
ASOP injected on Days 17 to 19 & $5 / 5$ & $7 \cdot 2$ \\
\hline
\end{tabular}

* $0.2 \mathrm{ml}$ pooled antiserum (ASOP) was injected subcutaneously at 11.00 hours.

\section{Effect of pooled antiserum on decidual cell response}

The results showed that the weight of the traumatized uterine horn in the control mice increased threefold compared with that of the untouched uterine horn $(635 \cdot 4 \pm 332 \cdot 0$ (S.D.) $\mathrm{mg}$ versus $243 \cdot 9 \pm 52 \cdot 3 \mathrm{mg}$ ). When ASOP was injected only on Day 4 of pseudopregnancy or on Days 1 to 3 , it failed to affect deciduoma formation and the weight of the traumatized uterine horn was similar to that of the controls $(643 \cdot 6 \pm 326 \cdot 0$ versus $206 \cdot 0 \pm 17 \cdot 1 \mathrm{mg}$, four mice, and 684.5 $\pm 345 \cdot 0$ versus $183 \cdot 1 \pm 33 \cdot 6 \mathrm{mg}$, four mice).

\section{DISCUSSION}

Immunological studies with ovine prolactin have indicated that the hormone gives a single precipitin line against its homologous antiserum (Levy \& Sampliner, 1962; Hayashida, 1962; Trenkle et al., 1963; Larson \& Assa, 1963; Sundaram \& Sonenberg, 1969). The antiserum prepared by us also gave a single precipitin line against ovine prolactin. When the antiserum was allowed to cross-react with ovine GH, however, a slight 'lingering reactivity' was observed, perhaps due to the contamination of GH in NIH prolactin.

The results of the various immunological techniques tested indicate that the absorbed antiserum to ovine prolactin possessed a high degree of specificity. 
The results presented here indicate that neutralization of endogenous prolactin, in normal cyclic female mice, caused a complete block of pro-oestrus. This effect is accompanied by inhibition of ovulation and the absence of newly formed CL in the ovaries of treated mice. Serum and pituitary prolactin levels have been reported to be very high during pro-oestrus (Niswender et al., 1969; Gay et al., 1970) and, in our study, the antiserum was able to neutralize this increase.

Although Niswender et al. (1969) have reported two peaks in serum prolactin concentration, one during placental formation and the other during parturition, the antiserum failed to cause complete resorption of implanted fetuses and did not delay or prevent parturition in our study (Table 2).

Hiroi (1971) and Macdonald et al. (1971) have reported ovine prolactin to be biologically active in the mouse and the rat as it prolongs the life-span of the CL in cyclic or pseudopregnant animals. Our results are in agreement with these observations since antiserum to prolactin shortened the duration of pseudopregnancy. Finn \& Martin (1967) have observed that large numbers of the epithelial cells of the uterine lumen and glands but very few of the stromal cells undergo mitoses on the 3rd day of pregnancy in mice. On the 4th day, however, the situation is reversed. This change in the pattern of cell division is considered to be due to the secretion of progesterone (Martin \& Finn, 1968; Finn \& Martin, 1969), a factor which plays an important role in the preparation of the uterus for implantation (Finn et al., 1969). The pooled antiserum thus failed to affect secretion of progesterone during early pregnancy. In contrast to our observations with antiserum to ovine LH (Munshi et al., 1972), the inability of the antiserum to affect early pregnancy in mice suggests that the luteal tissue is more readily influenced by LH than by prolactin.

\section{AGKNOWLEDGMENTS}

The ovine prolactin (NIH-P-S10), ovine LH (NIH-LH-S18), ovine FSH (NIH-FSH-S9) and ovine growth hormone (NIH-GH-S10) used in this study were gifts from the National Institute of Arthritis and Metabolic Diseases, National Institute of Health, Bethesda, Maryland 20014. The technical assistance of Mrs R. K. Nair, Mr A. S. Patankar and Mr V. M. Kamble are gratefully acknowledged.

\section{REFERENCES}

Astwood, E.B. \& Greep, R.O. (1938) Corpus luteum-stimulating substance in rat placenta. Proc. Soc. exp. Biol. Med. 38, 713-716.

Avrameas, S. \& Ternynck, T. (1969) The cross-linking of proteins with glutaraldehyde and its use for the preparation of immunoadsorbents. Immunochemistry 6, 53-66.

Cerrutti, R.A. \& Lyons, W.R. (1960) Mammogenic activities of the midgestational mouse placenta. Endocrinology 67, 884-887.

Davis, B.J. (1964) Disc electrophoresis. II. Method and application to human proteins. Ann. N.Y. Acad. Sci. 12, $404-427$.

Donovan, B.T. \& Lockhart, A.N. (1972) The gonadotrophins. In Modern Trends in Endocrinology, Ch. 1, Sect. 3, pp. 15-45. Eds F. T. G. Prunty \& H. Gardiner-Hill. Redwood Press Ltd, Trowbridge and London. 
Finn, C.A. \& Martin, L. (1967) Patterns of cell division in the mouse uterus during early pregnancy. 7. Endocr. 39, 593-597.

Finn, C.A. \& MaRtin, L. (1969) Hormone secretion during early pregnancy in the mouse. $\mathcal{F}$. Endocr. 45, 57-65.

Finn, G.A., Martin, L. \& Carter, J. (1969) A refractory period following oestrogenic stimulation of cell division in the mouse uterus. F. Endocr. 44, 121-126.

Gay, V.L., Midglex, A.R.,Jr \& Niswender, G.D. (1970) Patterns of gonadotropin secretion associated with ovulation. Fedn Proc. Fedn Am. Socs exp. Biol. 29, 1880-1887.

Grandison, L. \& Meites, J. (1972) Luteotropic action of prolactin during the estrous cycle of the mouse. Proc. Soc. exp. Biol. Med. 140, 323-325.

Hayashida, T. (1962) Immunological studies with pituitary prolactin. Ciba Fdn Colloq. on Endocrinology, 14, pp. 338-360. Eds G. E. W. Wolstenholme \& M. P. Cameron. Churchill, London.

Hrror, M. (1971) Prolactin bioassay-its sensitivity and stability. Endocr. jap. 18, 67-79.

KABAT, E.A. \& MAYER, M.M. (1961) Immunological and immuno-chemical methodology. In Experimental Immunochemistry, Ch. 2, pp. 22-72. C.C. Thomas. Springfield, Illinois.

Kwa, H.G. \& Verhofstad, F. (1967) Prolactin levels in the plasma of female rats. 7 . Endocr. 39, 455-457.

LARson, Z. \& Assa, S. (1963) Immunological investigations of sheep prolactin. Nature, Lond. 197, 299.

Levy, R.P. \& Sampliner, J. (1962) Prolactin: immunologic evidence of species specificity. Proc. Soc. exp. Biol. Med. 99, 672-673.

Lowry, O.H., Rosebrough, N.J., Farr, N.L. \& Randall, R.J. (1951) Protein measurement with the folin phenol reagent. $\mathcal{F}$. biol. Chem. 193, 265-275.

Macdonald, G.J., Yosminaga, K. \& GReEP, R.O. (1971) Maintenance of luteal function in rats by rat prolactin. Proc. Soc. exp. Biol. Med. 136, 687-688.

Malven, P.V. \& Sawyer, C.H. (1966) A luteolytic action of prolactin in hypophysectomized rats. Endocrinology 79, 268-274.

Martin, L. \& FinN, C.A. (1968) Hormonal regulation of cell division in epithelial and connective tissues of the mouse uterus. 7. Endocr. 41, 363-371.

Munshi, S.R. \& Nilsson, O. (1973) Morphological effect of antiserum to luteinizing hormone on early pregnancy in mice. 7. Reprod. Fert. 33, 127-128.

Munshi, S.R. \& RAo, S.S. (1965) An immunological study of sheep pituitary luteinizing hormone. Indian F. $\exp$. Biol. 3, 136-138.

Munshi, S.R. \& RAo, S.S. (1967) Biological specificity of antigens present in ovine luteinizing hormone. Indian 7. exp. Biol. 5, 135-140.

Munshi, S.R. \& RAO, S.S. (1968) Biological specificity of antigens present in ovine follicle stimulating hormone. Indian J. exp. Biol. 6, 47-48.

Munshi, S.R., Purandare, T.V. \& RaO, S.S. (1972) Effect of antiserum to ovine luteinizing hormone on corpus luteum function in mice. F. Reprod. Fert. 30, 7-12.

Munshi, S.R., Purandare, T.V. \& Rao, S.S. (1973) Effect of antiserum to ovine luteinizing hormone on uterine cell division during early pregnancy in mice. 7 . Endocr. 58, 123-124.

Neill, J.D., Freeman, M.E. \& Tillson, S.A. (1971) Control of the proestrous surge of prolactin and Iuteinizing hormone secretion by estrogens in the rat. Endocrinology 89, 1448-1453.

Niswender, G.D., Ghen, C.L., Midgley, A.R., JR, Meites, J. \& Ellis, S. (1969) Radioimmunoassay for rat prolactin. Proc. Soc. exp. Biol. Med. 130, 793-797.

Ouchterlony, O. (1949) Antigen-antibody reactions in gels. Acta path. microbiol. scand. $26,507$.

RAO, S.S. \& SADRI, K.K. (1959) Immunological studies with human semen and cervical mucus. Proc. 6th Int. Conf. plann. Parenth. pp. 313-318. Ed. L. N. Jackson.

Raghavan, V., Rao, S.S., Chaubal, U., Punjabi, J. \& Krishna, U. (1973) HCG levels during pregnancy in Indian women. Indian 7. med. Res. 61, 298-303.

Sundaram, K. \& Sonenberg, M. (1969) Immunochemical studies of human GH, ovine prolactin, ovine GH and a typical digest of bovine GH. 7. Endocr. 44, 517-522.

Trenkle, A., LI, C.H. \& Moudgal, N.R. (1963) Studies on pituitary lactogenic hormone. XXI. Immunochemical studies of the sheep hormone. Archs Biochem. Biophys. 100, 255-259.

Wuttke, W. \& Meites, J. (1970) Effects of ether and pentobarbital on serum prolactin and luteinizing hormone levels in proestrus rats. Proc. Soc. exp. Biol. Med. 135, 648-652. 